\title{
Advances in Education and Philosophy
}

\section{The Utilization of the Internet as Media Information and learning for Students in SMP Islam Athirah 1 Makassar}

Sutrisman Basir*

Public Administration, Universitas Puangrimaggalatung, Indonesia

\begin{tabular}{|c|l|}
\hline $\begin{array}{c}\text { *orresponding author } \\
\text { Sutrisman Basir }\end{array}$ & $\begin{array}{l}\text { Abstract: The use of the internet brings information resources closer to students so that } \\
\text { they can easily access information from various sources. The purpose of this study is to } \\
\text { analyze the information needs of students SMP Islam Athirah 1 Makassar on information } \\
\text { sources available on the internet. The basis of this study used is a survey study that } \\
\text { examines the role of the internet as a medium of information for students of SMP Islam } \\
\text { Athirah 1 Makassar. Whereas the type of research is quantitative. The number of sample } \\
\text { members for this study were } 162 \text { students, who came from Class VII = 77 students and } \\
\text { Class VIII = 85 students by means of proportional stratified random sampling. The } \\
\text { Accepted: } 23.12 .2018 \\
\text { results of this study indicate the level of internet use of students at Makassar Islamic } \\
\text { Middle School 1 in the category of frequent access both in terms of the type of } \\
\text { information and facilities offered all based on respondents' needs for information related } \\
\text { to science, information needs of students have different portions. But the tendency is } \\
\text { more in need of information relating to science than the need for entertainment } \\
\text { information. In seeking knowledge students prefer website facilities rather than choosing } \\
\text { information facilities to exchange knowledge information in the form of e-mail. } \\
\text { Keywords: Use of the Internet, Media information, Learning, Students. }\end{array}$
\end{tabular}

\section{INTRODUCTION}

The presence of the internet has changed most of the daily ways of life and human activities. The internet as an interactive media can be used by everyone to get information from all over the world. One of the users is students. Learners can use the internet as an alternative learning resource besides books to get more information [1]. The information society has the main need to fulfill the information needed to support various daily activities and other demands. The need for information is felt to continue to grow for someone every time he always has a high curiosity towards something. And curiosity arises when one wants to add to the long list of knowledge treasures [2].

This is also very possible in the information needs of young people who are sitting in junior high school. This is caused psychologically, adolescence is in the middle phase between childhood and adulthood. The search for identity and high self-need to be recognized becomes its own complexity. Internet usage is usually related to information retrieval and communication. Respondents have adjusted the duration of use with motives to meet the needs and opportunities to use the internet $[3,4]$.
Masllow and McClelland's motive theory explains that motive is an effort to fulfill all forms of needs that are influenced by advances that have been achieved and an environment that motivates efforts to fulfill needs [5]. Technological developments in communication that change the form of broadcasting and communication printing into a form of digital information can shorten the view to all kinds of information [6]. The speed of using and obtaining connections is influenced by many factors, including experience using, proficiency or knowledge of using computers, use of keywords, knowledge of the address to be addressed, and availability of computers $[7,8]$.

The use of the internet is expected to bring information sources closer to their students so that they can easily access information from various sources. For this reason, the author's background is to choose Makassar Athirah 1 Islamic Middle School as a place of research, because it is a superior school that is characterized by Islam and is culturally and globallyminded. Given the diverse information needs of students plus varied information channels. So in line with the development of science and technology, information has become an important part of the development of knowledge, even allowing changes in the way students think they make decisions to get information. Providing a quality source of information

Copyright @ 2017: This is an open-access article distributed under the terms of the Creative Commons Attribution license which permits unrestricted use, distribution and reproduction in any medium for non commercial use (NonCommercial, or CC-BY-NC) provided the original author and source are credited. 
tailored to the situation and conditions of the user is one of the most important elements. If the information needs are met, of course the use of the internet can be ascertained to run well $[9,10]$.

Therefore this research is intended to analyze the information needs of students of SMP Islam Athirah 1 Makassar towards the information sources available on the internet. This is done to further increase the effectiveness of students facing the current information era. Then it will be known how the use of the internet as a medium of information for students in Makassar, especially students of SMP Islam Athirah 1 Makassar.

\section{RESEARCH METHODS}

The basis of this study used is a survey study that examines the role of the internet as a medium of information for students of SMP Islam Athirah 1 Makassar. Whereas the type of research is quantitative. The research uses a questionnaire (questionnaire) to obtain the primary data of the study relating to the problem under study distributed to each respondent who has been selected as a sample. Students of the SMP Islam Athirah 1 Makassar who sit in class VII, VIII, and IX currently number 506 students but the study only provides a limit to the study population of students in grades VII and VIII. The number of sample members for this study were 162 students, which were sourced from Class VII $=77$ students and Class VIII $=85$ students by means of sampling using proportional stratified random sampling. Data analysis used in this research is quantitative data analysis to interpret data that has been processed in percentage form.

\section{RESEARCH RESULTS AND DISCUSSION Use of the Internet by Students of SMP Islam Athirah 1 Makassar}

The results of the study it was found that of the age group, most of the respondents who access the internet the most in this study were 13 years old $(53.7 \%)$. Then, from a number of reasons that prompted respondents to first use the internet, namely to add insight and knowledge was the reason that dominated respondents when they first wanted to use the internet $(38.3 \%)$. The choice of information sources is also based on habit patterns. Meyers, Nathan, and Saxton stated that habit patterns were interpreted if in the past a source of information could meet someone's needs then he would tend to use that source of information for later times [11].

Environmental conditions that are full of information will encourage students to try to find information positively (optimally). Conversely the environmental conditions around students who are uninformed will make students take certain steps to get information elsewhere. Thus the role of librarians as information specialists who have expertise about the content of information sources, including the ability to critically evaluate and filter them, is needed by monitoring the development of global information, selecting, filtering, and being able to select relevant and up to date interests. the user. So in terms of sources of learning when first using the internet, most of the respondents $(59.9 \%)$ in this study said they were first acquainted with and learned to surf from their friends.

The results of these findings have not been able to describe the true tendency of the students to know and use the internet for the first time. To find out more about the tendency for the first time among students of SMP Islam Athirah 1 Makassar to recognize and Dimensions of Interest in the Use of the Internet Examples of Internet Information Activities (Information Utility) Obtain information or news online. From what was revealed, 89 people $(54.9 \%)$ respondents, the majority of whom had known and used the internet for more than 3 years. Communication (Communication) Send or receive e-mail messages, to get information on online entertainment, the reasons that dominate the respondents want to use the internet 58 people $(35.8 \%)$.

The reason for encouraging respondents to use web-site facilities with respondents $(48.1 \%)$ is known that the motive for using web-sites to meet entertainment needs. To be able to carry out certain internet activities there are obstacles found in accessing the internet, the reasons that dominate, more when opening a web site are very slow with respondents 115 people $(71.0 \%)$. Qureshi revealed that the more students understand the sources of information that exist, it will cause these students to understand how to find the information needed so that it will improve the ability of students to use the available information media.

The findings of the data obtained by researchers revealed that 162 internet frequency respondents the most frequently used by respondents were> 4 times / week with the number of respondents who chose the answer there were 76 people or around $46.9 \%$. Then for the intensity of using the internet every time you access the most respondents do this time is 3-4 hours with the number of respondents as many as 56 people or $34.6 \%$. To find out more about the tendency of the intensity of internet use in students, the researcher will analyze further by linking the findings of internet access places that respondents often use.

It is known that 162 respondents who access the internet at home tend to use the internet with the most frequent frequency intensity, which is every day. Respondents who answered this were 106 respondents or $65.4 \%$. As with the frequency of the internet which is often used by respondents, most internet use for respondents who have an internet connection at home is the longest at each time accessing the internet, which is 3-4 hours. 
Looking at the findings that show that the average respondent who often accesses the internet at home with a frequency of time often used for $>4$ times a week accessing the internet with the average internet frequency frequently used by respondents is every day, it can be concluded that generally junior high school students SMP Islam Athirah 1 Makassar which has an internet connection at home is classified as a heavy user, an internet user. As according to The Graphic, Visualization and Usability Center, The Georgia Institute of Technology, internet users classified as heavy users are one of the characteristics of addicted internet users [12].

For respondents who often access the internet in internet cafes, 48 people or $29.6 \%$ of respondents almost all admitted that they access the internet in internet cafes. Internet users are categorized as medium users. Not only respondents who often access the internet at internet cafes are classified as medium users, respondents who often use public area wifi as their internet access place are also categorized as medium users. And 4 people or $2.5 \%$ for respondents who often access the internet by utilizing the internet services available at school.

Interests of Internet Usage in students of SMP Islam Athirah 1 Makassar from a number of internet activities submitted by researchers when distributing questionnaires it was found that there were several internet activities carried out among students, including searching for resources / materials related to subjects or schoolwork, looking for health information, looking for news or information on current events that occur in the world, both domestically and abroad, looking for information related to hobbies or interests, such as: automotive, reading books, looking for entertainment information, sending or receiving e-mail messages, , visiting social networking sites, such as: friendster, facebook, myspace, looking for images, such as cartoons, wallpapers, screen savers, liked artists, chatting with friends or other people, downloading songs, sending or receiving e-mail messages and playing online games.

To find out the interests of internet usage from accessing information conducted by junior high school students at Athirah, researchers refer to the classification of the interests of internet use as stated by Buente and Robbin [13]. First identifying information accessed at what internet is accessed by students of the Makassar Islamic Middle School 1, then probing several respondents with the motive to find out the reason or for the sake of what is actually for most respondents doing these internet activities.

Based on the findings of the data obtained by researchers, it was found that 162 respondents who accessed information on the internet, there were 161 people $(99.4 \%)$ respondents who accessed information related to science and internet frequency that respondents used most often 3-4 times / week. Then for a long time using the internet every time you access the most respondents do this time is 1-2 hours per 1 time access with the number of respondents as much as $99.4 \%$.

The results of these findings illustrate that the high information needs of students of SMP Islam Athirah 1 Makassar are in accordance with what was stated by Wilson that someone needs information to keep up with developments in the world around them. This is part of the human need for cognitive elements, namely the need to find order and meaning in the environment [14]. This need is closely related to one's motives to strengthen or add information, knowledge , and understanding of the environment. The environment has a big contribution in shaping the behavior shown by an individual. According to Pirolli, humans adaptively shape their behavior based on the information environment [15]. The information he obtained is believed to be able to build insight and his knowledge.

In connection with the social needs, students of the SMP Islam Athirah 1 Makassar also need information containing news, such as Politics, sports, lifestyle and health are additional information for students with their potential needs, and interests. This is related to the cognitive needs of individuals who need to actualize themselves. By doing self-actualization, they can continue to develop themselves and grow to reach their potential.

The results are known that respondents who access information that contains news on the internet with the frequency of frequency is the most rare, namely every day. Respondents who answered this were 142 people or $87.7 \%$ of the 162 respondents. As with the frequency of the internet which is often used by respondents, most of the internet use is for respondents who access information containing news even the longest duration of each time accessing the internet, namely 1-2 hours. With the intensity of access which is included rarely ie $<2$ times per week.

Entertainment information needs such as music, films and games and social networking sites (Facebook and Twitter) there are 157 people or $96.9 \%$ of 162 respondents. The data shows that respondents who often access entertainment information available on the internet know that the average internet frequency frequently used by respondents is 3-4 times / week with the average length of internet usage that is often used is at least among others, namely 1-2 hours of internet, According to Wersig, information needs are driven by a problematic situation where a person feels he must obtain input from sources outside himself. While Belkin, calling this an anomalous state of knowledge, 
one feels that the level of knowledge is not enough to deal with certain situations at that time [16].

The information needs of students of SMP Islam Athirah 1 Makassar will be of high entertainment. According to the acknowledgment of some respondents that they needed an entertainment to be made refresing and they did not want to miss the progress of technology. Fun for entertainment for someone who shows their interests and talents. The existence of these needs indicates the presence of cognitive needs (cognitive needs). Referring to Maslow's hierarchy of needs theory, their needs include the need to selfactualize which includes the need to continue to develop themselves and grow to reach their potential. Someone who has a particular hobby and continues to sharpen that is by being facilitated, it will make added value for them. Therefore, there is a need for information channels that can meet the information needs of their entertainment.

\section{The response of students from SMP Islam Athirah 1 Makassar to the role of the internet as an information medium}

The existence of technological determination that is so strong in human daily life has been able to change the existing model of communication, and even change human culture. With these new media discoveries it has shaped human life today to be far different compared to decades ago. One of them is the emergence of an information society that has the following characteristics: (1) information becomes a strategic weapon; (2) all high-value information will be stored in digital form; (3) world literature will appear in the form of electronic information; (4) human concepts of privacy, security and ownership change; (5) information exchange undermines cultural and regional boundaries.

The development of information technology and media has specifically been able to change culture and even human social life. There are positive and negative sides of the presence of communication technology. It could be that the use of communication technology is beneficial, for example increasing productivity, shortening time and distance. But, that does not mean it does not cause problems.

The results of processing data regarding respondents' responses to accessing information via the internet, it appears that 162 respondents generally 87 people $(53.7 \%)$ respondents gave very useful responses as information media, only 67 people $(41.4 \%)$ respondents who gave quite useful responses and a small proportion of only 8 people $(4.9 \%)$ respondents gave less useful responses.

The uses and gratification approach is one of the right theoretical foundations for the motives of media users. Because the assumption of the theory is the user who actively chooses the media used and the second is the media he uses can provide services or gratuities to the objectives to be achieved.

Results The entire study above is very much in line with the Uses and gratifications approach by Elihu, Katz, Jay Bluder and Gurvetch who suggested that this research model emphasizes the object of analysis of what people do with the media [17]. Middle School students SMP Islam Athirah 1 Makassar in particular became respondents in this study using the Internet both in terms of the type of information and the facilities offered were based on certain desires or motives of each individual or respondent who used the internet according to the needs of the respondents.

In treating the internet not only as a modern communication media, but also as one of the media information for students. Simple motives based on those needs are then grouped into 5 types of needs, namely cognitive needs, such as the need to know the school environment and obtain information on actual and fast information. Affective needs such as strengthening emotional experiences and integrative needs such as strengthening self-confidence and self-stability by exchanging messages are personal to the young without having to express genuine identity. The need to strengthen contacts, by fostering and establishing communication with fellow students and teachers in schools. And the need for entertainment to release tension by looking for entertainment in the form of games and more through the internet.

It appears in the results of the study as mentioned in terms of motives, generally respondents using the internet are motivated by motives to meet cognitive needs and entertainment needs (diversion). This can be proven that generally respondents prefer information related to science, and choose Web-site facilities rather than choosing information facilities in the form of e-mail.

\section{CONCLUSION}

Information needs of students have different portions. For students of SMP Islam Athirah 1 Makassar they need more information related to science than the need for entertainment information and contain. This is because of the characteristics of the students who they are in adolescence who need the information needed. The information needs of these junior high school students need to get a response from the internet, one of which is through the availability of information resources. The level of internet use of students at Makassar Islamic Middle School 1 is categorized as often accessing both in terms of types of information and all offered facilities are based on respondents' need for information related to science in accordance with role theory that the social role an individual carries strong influence in directing behavior including behavior in finding information. 


\section{REFERENCES}

1. Crystal, D. (2011). Internet linguistics: A student guide. Routledge.

2. McDermott, R. (1999). Why information technology inspired but cannot deliver knowledge management. California management review, 41(4), 103-117.

3. Nalwa, K., \& Anand, A. P. (2003). Internet addiction in students: A cause of concern. Cyberpsychology \& behavior, 6(6), 653656.

4. Ryan, M. L., Shochet, I. M., \& Stallman, H. M. (2010). Universal online interventions might engage psychologically distressed university students who are unlikely to seek formal help. Advances in Mental Health, 9(1), 73-83.

5. Pardee, R. L. (1990). Motivation Theories of Maslow, Herzberg, McGregor \& McClelland. A Literature Review of Selected Theories Dealing with Job Satisfaction and Motivation.

6. Fitzsimmons, J. A., Fitzsimmons, M. J., \& Bordoloi, S. (2006). Service management: Operations, strategy, and information technology. New York: McGraw-Hill.

7. Afshari, M., Bakar, K. A., Luan, W. S., Samah, B. A., \& Fooi, F. S. (2009). Factors affecting teachers' use of information and communication technology. Online Submission, 2(1), 77-104.

8. Dusick, D. M. (1998). What social cognitive factors influence faculty members' use of computers for teaching? A literature review. Journal of Research on Computing in Education, 31(2), 123-137.

9. Morahan-Martin, J., \& Schumacher, P. (2000). Incidence and correlates of pathological Internet use among college students 2$\}$. Computers in human behavior, 16(1), 13-29.

10. Metzger, M. J., Flanagin, A. J., \& Zwarun, L. (2003). College student Web use, perceptions of information credibility, and verification behavior. Computers \& Education, 41(3), 271290.

11. Meyers, E. M., Nathan, L. P., \& Saxton, M. L. (2007). Barriers to information seeking in school libraries: conflicts in perceptions and practice. Information Research, 12(2).

12. Surya, Y. W., \& Unair, D. J. I. K. F. (2002). The Internet And Online Journalism In Indonesia. Society, culture and politics: the bulletin of the Faculty of Social and Political Sciences, Airlangga University, 15 (1-4).

13. Buente, W., \& Robbin, A. (2008). Trends in Internet information behavior, 20002004. Journal of the American Society for Information Science and Technology,59(11), 1743-1760.

14. Kollmuss, A., \& Agyeman, J. (2002). Mind the gap: why do people act environmentally and what are the barriers to pro-environmental behavior?. Environmental education research, 8(3), 239-260.

15. Pirolli, P. (2007). Information foraging theory: Adaptive interaction with information. Oxford University Press.

16. Pendit, P. L. (2003). The use of information technology in public information services: an interpretative study of structural change via technology in the Indonesian Civil Service.

17. Nnamdi, B. (1995). Media Uses and Gratifications: A Review. Africa Media Review, 9(3). 